\title{
'Yo antes no reciclaba y esto me cambio por completo la consiencia': intercultural citizenship education in the English classroom
}

\section{Melina Porto}

Instituto de Investigaciones en Humanidades y Ciencias Sociales (Institute of Research in the Social Sciences and the Humanities), Facultad de Humanidades y Ciencias de la Educación (School of Humanities and Sciences of Education), Universidad Nacional de La Plata and CONICET (Consejo Nacional de Investigaciones Científicas y Técnicas), La Plata, Argentina

\begin{abstract}
This article describes a telecollaboration project about the environment in the primary English as a foreign language classroom carried out in 2013/ 2014 between Argentina and Denmark. It combines English language teaching with intercultural citizenship education and forms part of a network of projects in Europe, the US and East Asia. This is the only one set in the primary school context and in Latin America. After some preparatory work, the Argentinian and Danish children met online through Skype, using English, Spanish and Danish, to design a collaborative poster to raise awareness of the importance of taking care of the environment. Conversational and documentary data were collected and analysed qualitatively, in this case focusing on the Argentinian perspective. With a critical literacy conceptualisation, the project demonstrates growth in self/intercultural awareness, criticality and social justice responsibility, and the emergence of a sense of community of transnational peers amongst the children involved.
\end{abstract}

\section{ARTICLE HISTORY}

Received 11 August 2016

Accepted 7 November 2016

\section{KEYWORDS}

Intercultural citizenship; (foreign) language education; online transnational project; Argentina

\section{Introduction}

The comment in the title, 'Yo antes no reciclaba y esto me cambio por completo la consiencia' [I wasn't used to recycling and this totally changed my mind] belongs to Azul (pseudonym), a 10year old Argentinian child reflecting on her participation in the intercultural citizenship project described in this article. Her words illustrate the profound changes that the project brought about in the children involved, in this case in Azul's attitudes and actions towards the environment in her local context.

The purpose of this article is to describe an intercultural citizenship project in the English as a foreign language (EFL) classroom. After a general overview of its stages for implementation in the classroom and the methodology from a research perspective, the theory upon which it rests is described. Findings are illustrated with student samples, followed by simple recommendations for teachers.

\section{Overview of the project and this research}

This telecollaboration project, framed within what is called 'intercultural citizenship education', was designed as a case study (Gomm, Hammersley, and Foster 2000; Mertens 2015; Yin 2009), 
addressed the topic of the environment in primary school, in particular in the EFL classroom, and took place in 2013/2014 (see Porto 2016 for details). Participants were fifty 5th and 6th form children in Argentina at a state primary school in the city of La Plata, who were 10-11 years old at the time and had A1 level of English according to the Common European Framework of Reference (Council of Europe 2001); and twenty 7th form children in Denmark at an international school in Copenhagen, who were 12-13 and had an A2 level of English. All children were middle-class, lived in literacy-rich environments and both schools were urban and well-equipped (computer labs, Internet connection, library, open playgrounds, qualified teachers, etc.).

It is important to note that the project took place between September 2013 and March 2014 but the preparatory work by teachers and researchers began in 2012. The idea developed when the author of this article, researcher in Argentina, and Dr Petra Daryai-Hansen, researcher in Denmark, met online in Cultnet (http://cultnetworld.wordpress.com) - a network of researchers created by Michael Byram 20 years ago that gathers teachers and researchers interested in foreign language teaching and its cultural dimension. Planning took place during 2012 and a pilot study was undertaken in Argentina in the first semester of 2013.

The project had linguistic, intercultural and citizenship aims as follows: acknowledge linguistic diversity in Spanish, Danish and English, develop language awareness and vocabulary related to the topic, develop critical literacy practices, engage in intercultural dialogue using EFL and lingua franca, develop environmental awareness and practices (e.g. recycling, buying eco-friendly products), contribute to making the world a greener place both locally and globally, and foster values such as respect, mutual understanding and social and civic responsibility. These intercultural and citizenship aims do not form part, in general, of the foreign language classroom.

The project was designed with a project-based and task-based framework and builds on the gap identified by Copland and Garton $(2014,227)$ in English language education, namely that 'there remains a lack of classroom-based studies and "young learners" in general remains an underresearched area'. It had four stages: introductory, research, intercultural dialogue, and citizenship. In the introductory and research phases, in their EFL lessons, before meeting online, the Argentinian and Danish children researched about the environment in their own countries: they searched for information and read critically in Spanish and Danish (their native languages) and in English (foreign language for everyone). They read (audio) visual media images and texts related to the environment, produced in each country, and with a critical perspective they engaged in discussion using the worksheet in Figure 1. They shared their analyses using a wiki that we named

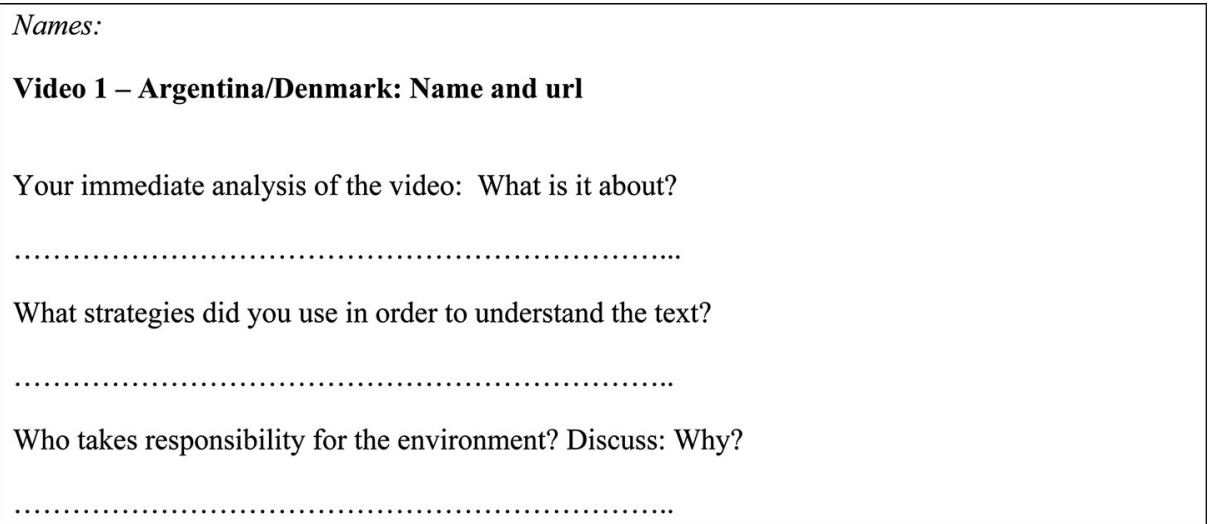

Figure 1. Media analysis worksheet. 
What green crimes do you know? Who commit them? Who are the victims?

Walk around your school and ask your parents to go for a walk in your neighbourhood. Identify the green crimes you see. You can take photographs using cameras, cell phones, and iPods or simply take notes.

We will share findings next class.

Figure 2. Green crimes worksheet.

\begin{tabular}{|l|l|l|}
\hline What do you find? & How many items? & Could this item be recycled? \\
\hline & & yes / no / perhaps \\
\hline & & yes / no / perhaps \\
\hline & & yes / no / perhaps \\
\hline
\end{tabular}

Figure 3. Trash analysis worksheet.

Worldgreenweb and which became a virtual classroom. We followed the considerations and recommendations in O'Dowd (2015) to use this wiki.

Then they made a list of green crimes that they identified in their schools and local communities (Figure 2) and registered those crimes through video or photographs. They also implemented a trash analysis project in which, wearing gloves, they examined the waste in the school bins, listing and classifying what they found (Figure 3). They surveyed relatives and friends to learn about their habits concerning the environment (Figure 4). They uploaded their drawings, videos, photographs and charts summarising the mini-projects (trash analysis and survey) to the wiki with the help of their teachers and they compared and discussed results using the chat function. Parents were given access to the wiki and were invited to comment.

In the intercultural dialogue stage, the Argentinian and Danish children worked in collaboration to design posters to raise the awareness of people about environmental issues. This task was intended to foster 'a creative desire and the need for learners to say something new' (also Maley and Bolitho 2015; Tin 2013,396) or in other words, to convey their own ideas about the topic. They engaged in online communication using Skype and the wiki during school time, guided by their teachers, and used English, Spanish and Danish. Mixed nationality groups were formed and each group thought about the purpose, content and language(s) of the poster using the worksheet in Figure 5 as a guideline. One of the collaborative posters appears in Figure 6.

In the citizenship phase, the children in each country took action in their communities and engaged in concrete civic initiatives. For example, the Argentinian children recorded videos and uploaded them to Facebook or YouTube (http://www.youtube.com/watch?v = uysvpqx2vN0, http://www.youtube.com/watch?v= DjgTR6QeetQ, http://www.youtube.com/watch?v = nGE9oq3h Tdo); they were interviewed by a local journalist and the collaborative posters were published in the local newspaper (Figure 7; http://www.eldia.com.ar/edis/20131121/Alumnos-Plata-Dinamarcaabrazan-medio-ambiente-laciudad2.htm); and they designed a street banner (Figure 8) which they hung across the school street and can be seen in the newspaper article. Both the Argentinian and Danish children created a video summarising the project and uploaded it to YouTube.

The project produced recorded conversational data comprising Skype conversations, chats in the wiki, class discussions and group interviews; and documentary data comprising the 


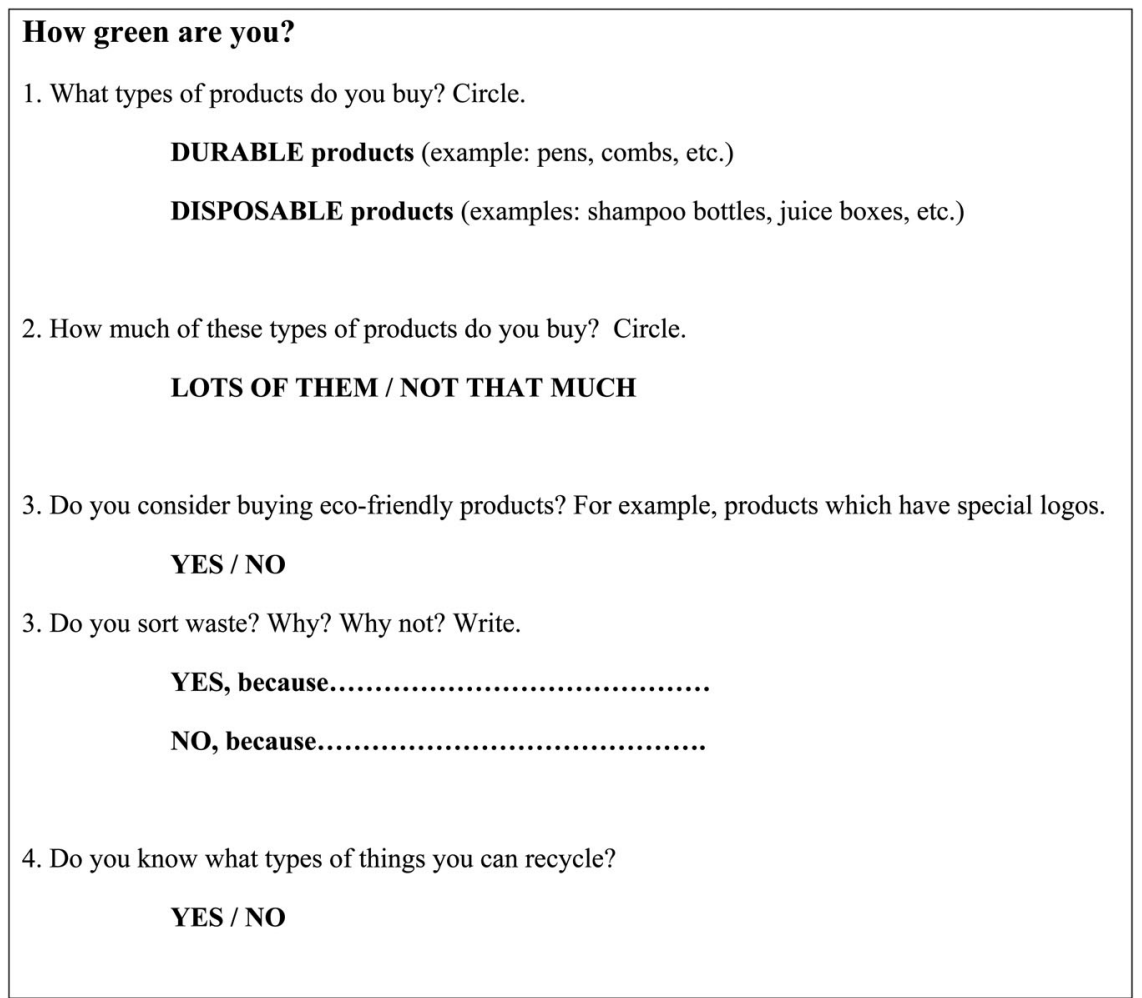

Figure 4. Survey worksheet.

collaborative posters, student productions (songs, videos, drawings, etc.), reflection logs and the Autobiography of Intercultural Encounters (hereafter AIE) (Byram et al. 2009). This Autobiography is a resource created by the Council of Europe which is intended to foster reflection on intercultural encounters as a step towards learning from those encounters. The Argentinian children used a version for young learners in Spanish while the Danish children used the English version because they were more proficient, and both worked on it after the project was over. Data were analysed using content analysis (Cohen, Manion, and Morrison 2011). Parents signed consent forms and all student names are pseudonyms. Data extracts appear verbatim and translations into English appear between brackets. This article focuses on the Argentinian perspective.

\section{Theoretical framework}

Stated briefly, this project is based on:

(1) A constructivist perspective on learning, a conception of language use as social and communicative practice, a socio-cultural conception of reading in general, and cultural perspectives on education in a foreign/second language in particular (Gee 2012). Also, the tasks proposed for the project in its four stages described before (introductory, research, dialogue and action) rest on a multiliteracies perspective (involving new literacies and multiple languages) (García 2009). In this article, 'text' means whatever can be 'read' and 'interpreted', in varied sign systems, mediums and languages, for instance print, non-print, visual, digital, multimodal, etc. (Hagood and Skinner 2012; Handsfield, Dean, and Cielocha 2009). 
In the Skype meeting, you will plan together a poster (or video, leaflet, mural, etc.) to raise awareness of the importance of protecting the environment. You have to agree on the form, the content, the languages and the division of work.

Group members (names): Introduce yourself (name, age, school, family, hobbies, etc.)

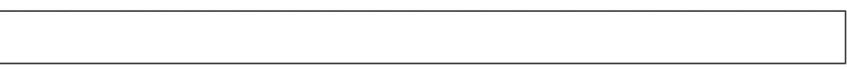

Responsible: Denmark:

email:

Responsible: Argentina:

email:

1. The form (a video, a poster, a song, etc.)

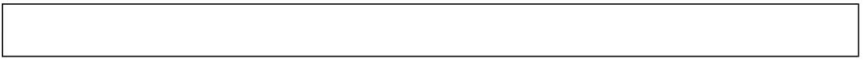

2. The content (recycling, transport, air pollution, waste of water, waste of power, etc.): What will the poster (video, song, etc.) focus on?

3. The visuals/images: What visuals/images will you include?

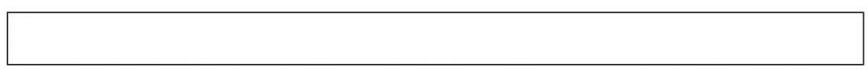

4. You can use the following languages: Danish, English, Spanish.

What will be said in English?

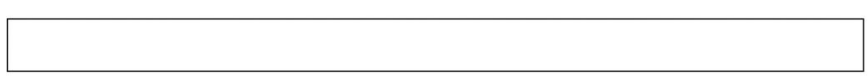

What will be said in Danish?

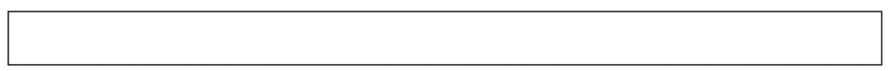

What will be said in Spanish?

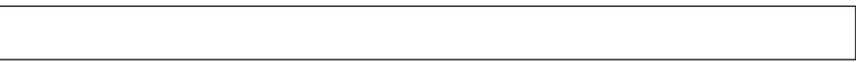

Figure 5. The Skype meeting between Argentina and Denmark. Worksheet.

(2) The concept of education for intercultural citizenship in the (foreign) language classroom (Byram et al. 2016; Byram 2008, 2014a,b) that combines foreign language education and citizenship education, and is described next. 


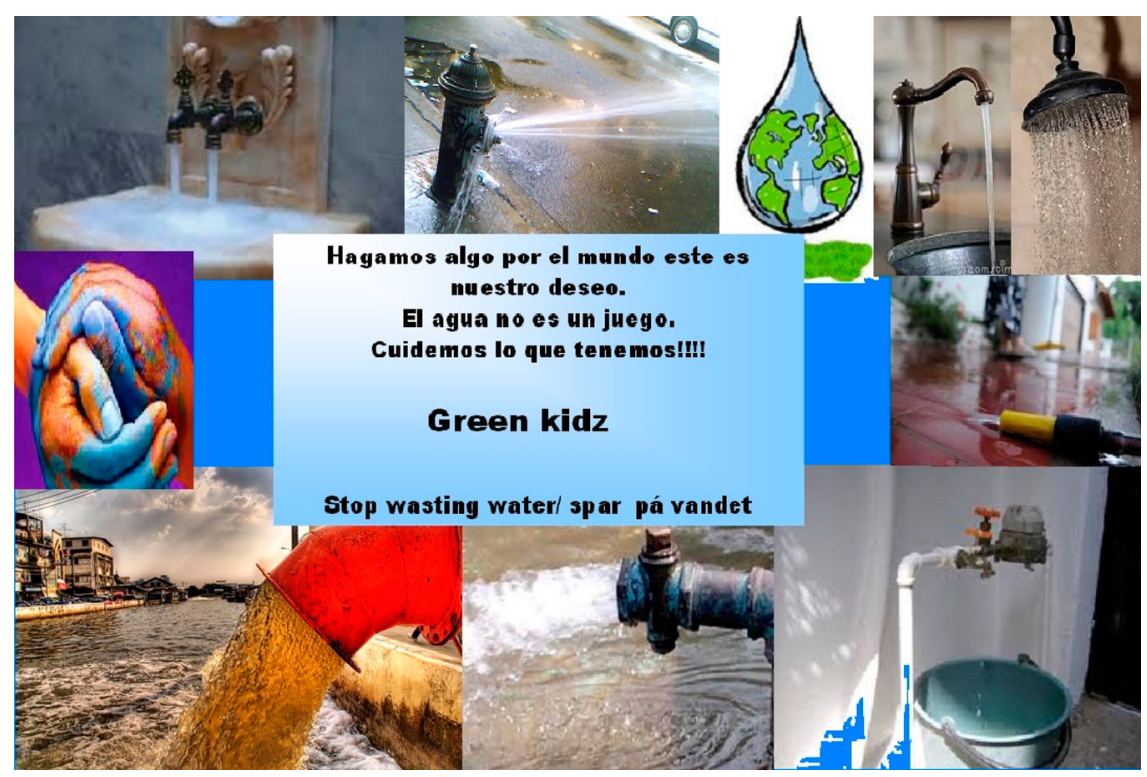

Figure 6. Collaborative poster between the Argentinian and Danish children in English, Spanish and Danish.

\section{Alumnos de La Plata y Dinamarca se abrazan por el medio ambiente}

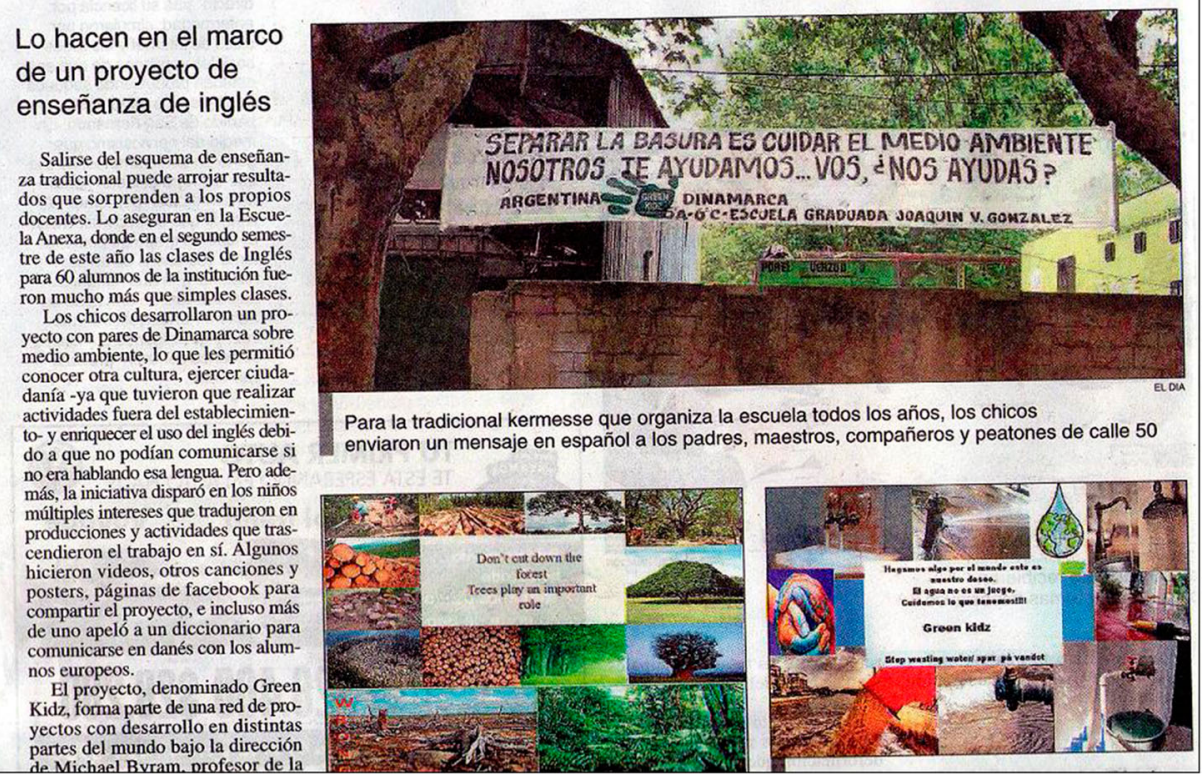

Figure 7. Civic action in the community (citizenship dimension of the project): Article about the project in the local newspaper (in the city of La Plata, Argentina) after the children had been interviewed by a local journalist. The posters that the Argentinian and Danish children produced in collaboration can be seen in the article. The banner in Figure 8 can also be seen there. 


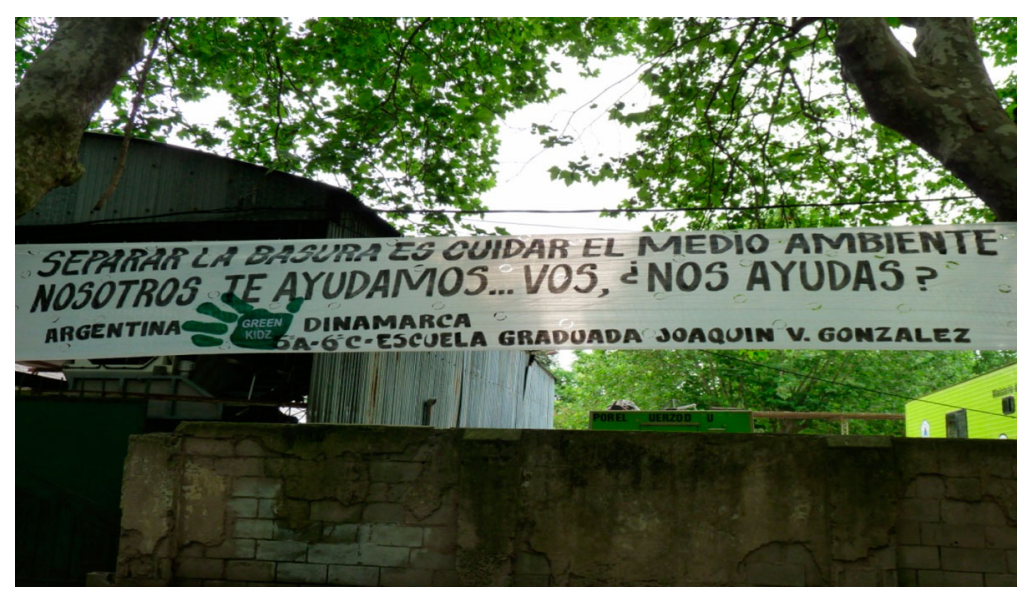

Figure 8. Civic action in the community (citizenship dimension of the project): Banner in the primary school in La Plata, Argentina. The banner can be seen in the newspaper article in Figure 7.

\section{Combining language education and intercultural citizenship education}

The starting point for this project is that English language teaching (ELT) and (foreign) language education in general have educational as well as instrumental purposes. The proposal moves ELT beyond linguistic and communicative competence, dominant in the 1980s and 1990s, towards intercultural communicative competence (ICC) (Byram 1997; Kramsch 2011) and citizenship education with a human rights perspective (Dunhill 2016; Osler and Starkey 2010). The argument is that a combination of language teaching and citizenship education has an educationally significant potential and it was first put forward by Byram (2008). The citizenship dimension links the ELT classroom with the community and becomes the content of foreign language teaching. Teaching language through meaningful content is an approach called CLIL (Content and Language Integrated Instruction) (Cenoz 2015). It is worth noting that these instrumental and educational perspectives on ELT in combination using CLIL are relevant also for all subjects in the primary school curriculum (e.g. Ní Chróinín, Ní Mhurchú, and Ceallaigh 2016).

\section{Intercultural communicative competence}

In (foreign) language education, the shift from linguistic and communicative competence to ICC began with Byram (1997) and his Model of Intercultural Competence. The model has evolved since then but essentially it comprises different dimensions of knowledge, skills and attitudes, beyond the linguistic, that the author calls savoirs, and which he argues form part of language education, specifically foreign language education. They are: savoir être (attitudes of curiosity and inquisitiveness), savoirs (knowledge of the ways of life in a given society or context, for instance work, education, traditions, history, dress codes, food, etc.), savoir comprendre (skills of interpreting and relating those savoirs), savoir apprendre/savoir faire (skills of discovery and interaction) and savoir s'engager (critical cultural awareness).

\section{What is intercultural citizenship?}

Intercultural citizenship (Byram 2008, 2014a,b) takes ICC a step further emphasising three key aspects: 
- The relational: It refers to getting involved with others. In this project, the children became intercultural speakers or intercultural mediators (Byram 2009) and used EFL and lingua franca in addition to their native languages (Spanish, Danish).

- The critical: It refers to analysis and reflection of one's thoughts and actions, and those of others, through a comparative perspective which in this project involved communication amongst children in three different languages and interaction amongst their diverse ideas, values and beliefs about the environment.

- The civic/citizenship: It refers to students engaging in civic action in their communities, that is, taking action beyond the classroom and the school, and the street banner that the Argentinian children designed and hung across their school street is an example (Figure 8).

\section{How is intercultural citizenship put in practice in the classroom?}

A project in the (foreign) language classroom which aims to adopt an intercultural citizenship orientation has the following characteristics (Byram et al. 2016):

(1) citizenship is the content of lessons and addresses themes of social import that highlight the universal principles of democratic citizenship and human rights education (Dunhill 2016; Osler and Starkey 2010) such as the environment, ecology, languages, peace and conflict, diversity, linguistic and other rights;

(2) students from two or more countries (or different regions within one country; or different schools in the same community; etc.) collaborate in a (transnational) project and develop a sense of (transnational) identification amongst themselves;

(3) students analyse their naturalized assumptions, their taken for granted beliefs and challenge them;

(4) students engage in critical thinking but go beyond thought to take action in the community (at local, regional, national or global levels).

\section{What competences, abilities or skills does intercultural citizenship involve?}

Byram (2008) and Byram et al. (2016) say that the competences, abilities or skills that intercultural citizenship develops are:

- consciousness-raising: observing, describing, analysing, discovering;

- comparative interpretation: comparing, contrasting, relating, de-centring, perspective-taking, interpreting; and

- critical thinking: critical reflexivity, critical action in the world (when students engage in community involvement).

\section{What domains of criticality does intercultural citizenship involve?}

Critical thinking or criticality is a characteristic of education generally observed in Higher Education and more randomly in primary school (Barnett 1997) and this project shows that criticality can be developed in this context in the foreign language classroom in three domains:

(1) Propositions: The content of (foreign) language education. In this project, it involved learning about the environment and how to take care of it in daily life. 
(2) The internal world: Analysis, self-reflection and evaluation of one's values, views, presuppositions, etc. It involves stepping outside one's views (de-centring) and considering different perspectives (perspective-taking).

(3) The external world: Critical transformation revealed through actions of civic or social import in the community.

\section{Intercultural citizenship at present}

Very few intercultural citizenship studies as conceptualized before exist. Byram et al. (2016) present cases in 11 countries (Argentina, China, Denmark, Hungary, Italy, Japan, South Korea, Sweden, Taiwan, the United Kingdom and the USA), which are examples of how learners of different ages and different levels of linguistic competence in different languages can be taught on the basis of the principles of intercultural citizenship enunciated before. Of the network of projects led by Byram, this is the only one located in primary school and also in Latin America.

\section{Project findings}

The content analysis undertaken revealed three key findings associated with the central elements of the theory of intercultural citizenship:

(1) a sense of bonding between the Argentinian and Danish children developed, called 'transnational identification'

(2) the children developed intercultural citizenship skills

(3) the children developed critical cultural awareness, that is, criticality involving concrete civic actions in the community.

\section{A transnational identification developed}

That a sense of bonding between the Argentinian and Danish children developed during the intercultural dialogue stage of the project means that they temporarily left aside their identification as Argentinian or Danish and worked in genuine cooperation with their international peers. The use of first person plural forms in all data types (collaborative posters, autobiographies of intercultural encounters -AIE-, chats in the wiki, Skype conversations, interviews, student productions) is evidence of this transnational identification (evidence in italics).

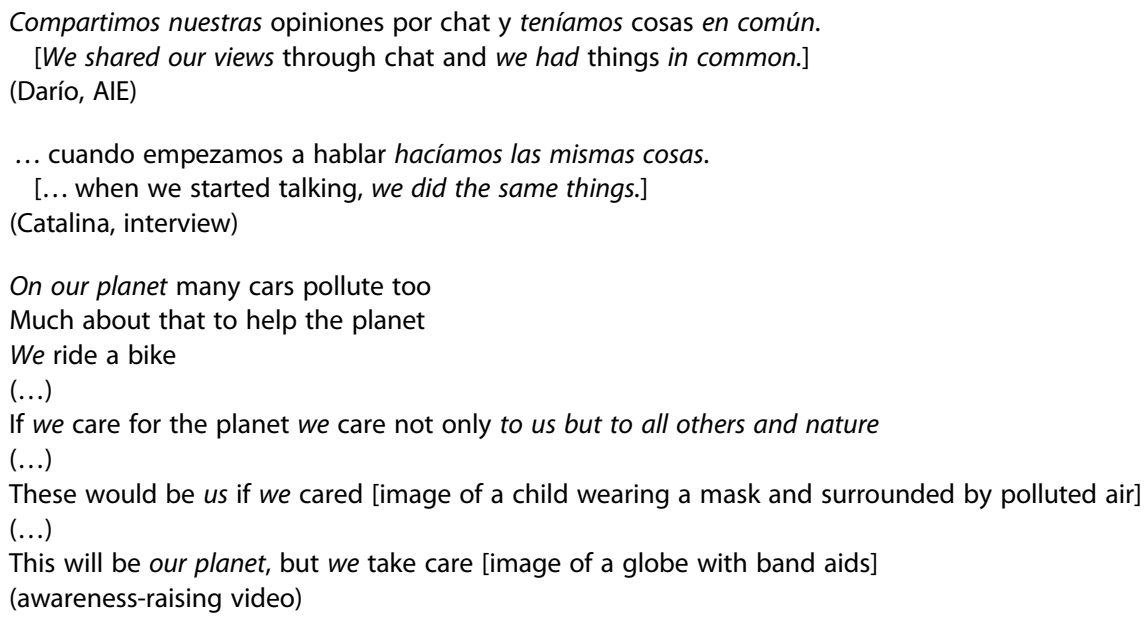


The children perceived English as a driving force in this international contact and as a tool that helped them see the commonalities they shared. English was a shared language to interact with each other and feel the sense of communion and belonging that in the theory is referred to as 'transnational identification' (Byram et al. 2016).

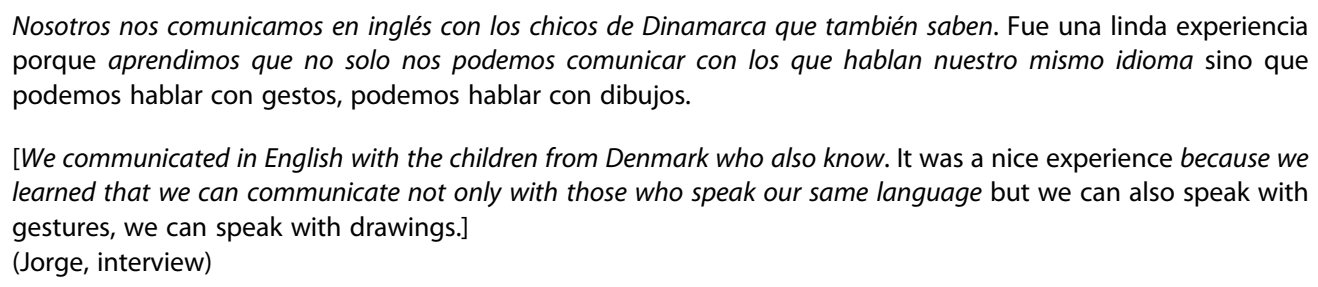

[We communicated in English with the children from Denmark who also know. It was a nice experience because we learned that we can communicate not only with those who speak our same language but we can also speak with gestures, we can speak with drawings.]

(Jorge, interview)

The following extract from a chat in the wiki shows that the children used English initially, before working on the collaborative posters, to achieve a sense of bonding by discovering what brought them together, in this case music and an interest in each other's native languages.

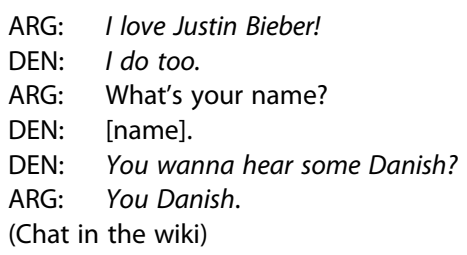

In sum, by taking part in this project the Argentinian and Danish children worked in cooperation and developed a bond amongst themselves that in the theory of intercultural citizenship is called 'transnational identification'.

\section{The children developed intercultural citizenship skills}

Linguistic evidence of the skills involved in intercultural citizenship was found in all data types. For instance, consciousness-raising through observation, discovery, description and analysis was frequent when the children reflected about the environment:

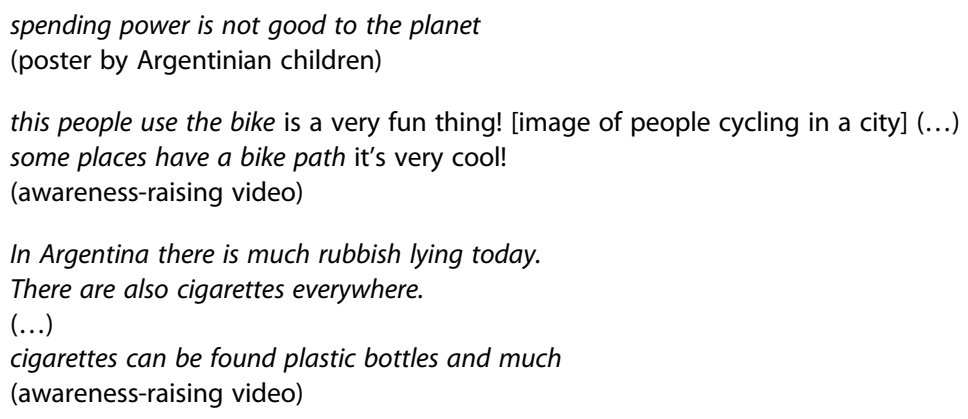

The process of comparative interpretation involving comparing and contrasting was evident in the simultaneous use of the languages involved in the project. For instance, one of the collaborative posters included the following text in Spanish, English and Danish:

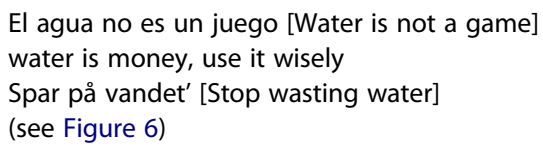


It also occurred when the children carried out a survey in each country to learn about the environmental habits of relatives and friends (e.g. buying green products, recycling at home and at school, turning off lights when leaving home, etc.) (see Figure 4). Here the students went beyond comparing and contrasting and engaged the skills of relating, de-centring and perspective-taking, in particular when they shared the results of their surveys in the wiki and talked about environmental habits in both countries during class discussions. For example, Ramiro learned that the Danish children were not used to recycling at school:

Creo que hubo escasas diferencias como que en su escuela no separaban la basura

[I think there were few differences like in their school they didn't sort out trash]

(RamitoAIE).

In one of the awareness-raising videos the Argentinian children wrote this message where comparison and contrast are also evident. The children learnt that their Danish peers cycle to school and other activities whereas this is rare in their country.

This family use this bike every day we can try [image of a father and child in a bike, and another child in another bike]

Finally, critical thinking and reflexivity were also important. Involved here is an evaluative stance revealed in expressions like 'is not good' and 'is better of for':

spending power is not good to the planet

bicycle use is better of for environment

(poster by Argentinian children)

This is a very good idea! [using bikes instead of cars - image of bikes and cars]

(awareness-raising video)

But not only is junk but it also wasted a lot of water, polluting factories, many cars and few bicycles

(awareness-raising video)

This cars are polluting too much

(awareness-raising video)

Ramiro said that they were all rejecting green crimes to raise awareness around the world and they did that using the wiki too:

estamos colaborando otro paises para decirle no a los crímenes verdes y crear conciencia en todo el mundo. A través de la wiki también.

["we are collaborating [with] other countries to say no to green crimes and raise awareness all over the world. Through the wiki too]

(Ramiro,AIE)

The plural forms in bold are simultaneously evidence of the transnational identification mentioned before.

Starting from the identification of differences (evidence in italics in the data excerpts below), the children focused on their commonalities and what brought them together (in bold), and this was essential to allow de-centring and perspective-taking, that is, noticing difference, considering perspectives different from one's own and putting oneself in the shoes of the other (underlined).

Si nosotros hablamos en español y en inglés y ellos a parte hablan en inglés y danés también las diferencias eran las edades eran diferentes otros tenían 13 o 14 y nosotros teniamos 10 o 11 yo tengo 11 .

[Yes we speak Spanish and English. And besides, they speak English and Danish we were different ages too some of them were 13 or 14 and we were 10 or 11 Ím 11.].

(Eliseo, AIE)

\footnotetext{
A ellos les gustaba One Direction a nosotros también les gustaba bailar a nosotros también. [They liked One Direction and so did we they liked dancing and so did we.]

(Valentina, AIE)
} 
Me sorprendí porque teníamos que hablar siempre en inglés. [I was surprised because we had to speak English all the time.] (Marcos, AIE)

Fue un día extraño sólo porque saber que estar conectado con personas de otro país ya es raro. [lt was a strange day because knowing that we had to be connected with people from another country was weird enough.]

(Ramiro, AIE)

Creo que ellos se sintieron muy felices por haber hecho algo por el mundo. Me di cuenta por todo el esfuerzo que pusieron en el poster y las ganas que tenían de hacer este proyecto.

[I think they felt very happy about having done something for the world. I realised that because of the great effort they put in making the poster and the engagement they kept throughout the project.]

(Carolina, AIE)

To round off, the different data types show that the children developed the skills involved in intercultural citizenship, namely consciousness-raising (observing, describing, analysing and discovering), comparative interpretation (comparing, contrasting, relating, de-centring, perspective-taking and interpreting) and critical thinking (critical reflexivity and critical action in the world).

\section{The children developed critical cultural awareness}

The three dimensions of criticality described by Barnett (1997) were present in this study. The first one, propositions and ideas, that is,what the children learned as the content of EFL instruction, involved here information about the Danish peers as one AIE shows:

Me parece que todos aprendimos de sus cosas, escuela y gustos y ellos aprendieron eso de nosotros.

[I think that we all learned about their things, school and likes, and they learned that about us]

(Valeria, AIE)

and also information about the environment and how to protect it

transport is bad for the environment ... like cars, trains and planes

(chat in the wiki)

The second dimension of criticality is the internal world, or in other words, critical thinking involving self-reflection, analysis and evaluation:

\footnotetext{
El agua no es un juego [Water is not a game]

water is money, use it wisely

Spar på vandet' [Stop wasting water]

(Collaborative poster, Figure 6)
}

Si tomé conciencia. Porque me di cuenta que tan solo con un pequeño esfuerzo podemos mejorar el mundo [Yes, I became aware. Because I realised that we can make a better world with very little effort]

(Jorge, AIE)

no street littering because it pollutes the environment (poster by Argentinian children)

The third dimension of criticality is the external world, that is, the actions that the children took as an outcome of the thinking and learning triggered by the project, actions of civic and social character. Criticality here is critical cultural awareness (Byram 1997, 2009) meaning that the children thought of concrete actions to protect the environment in their local communities and implemented those actions. For instance, they created videos and shared them in YouTube and Facebook, they designed a street banner (Figure 8) and were interviewed by a local journalist (Figure 7). In their videos they explicitly encouraged others to take care of the planet by using imperatives: 


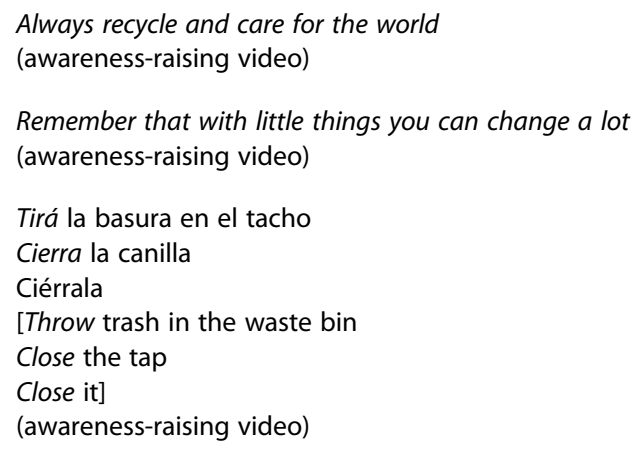

They were thinking of themselves as members of a global community with responsibilities towards the environment and encouraged others to join them:

Want this in the world?

you expect? let's save the planet

Always recycle and care for the world.

And little by little we will also to do a better place to live

(awareness-raising video)

We must do something!

(awareness-raising video)

Looking and all this video, I hope that serve to see what happens in the world

(awareness-raising video)

Entre todos cuidemos la ciudad ... No queremos esto en nuestra ciudad

[Let's all take care of the city ... We don't want this in our city]

(awareness-raising video)

In so doing, they experienced a sense of joy and attempted to foster the feeling in others too:

And you can have fun saving the planet
It's a very fun thing
(awareness-raising video)
This people use the bike is a very fun thing!
(awareness-raising video)

They also implemented changes in their daily habits. The children registered and reflected on these actions in their AlEs:

Cada vez que vea a alguien tirar basura le exijire que la levante y que la tire al tacho

[every time I see someone drop litter I will demand that they pick it up and throw it in a bin]

(Laura)

Yo antes no reciclaba y esto me cambio por completo la consiencia

[ wasn't used to recycling and this totally changed my mind] (Azul)

[voy a] seguir hablando sobre el proyecto con los demás y tratar de cuidar el medio ambiente

[[I will] keep telling others about the project and try to take care of the environment]. (Verónica)

Interestingly, the Argentinian children were very motivated by the project and engaged in additional activities not planned by the teachers. For instance, one group, in their own time outside lessons, created an awareness-raising poster (Figure 9) and brought it to class one day.

These children chose the topic of power with the aim to foster consciousness about the importance of not wasting power. Combining images and language, and manipulating language (the letter ' $o$ ' in 'power' is replaced by a light bulb) -that is, creativity in Tin's (2013) sense referred to earlier - they addressed their imagined readers, the readers of this poster, by talking directly to 


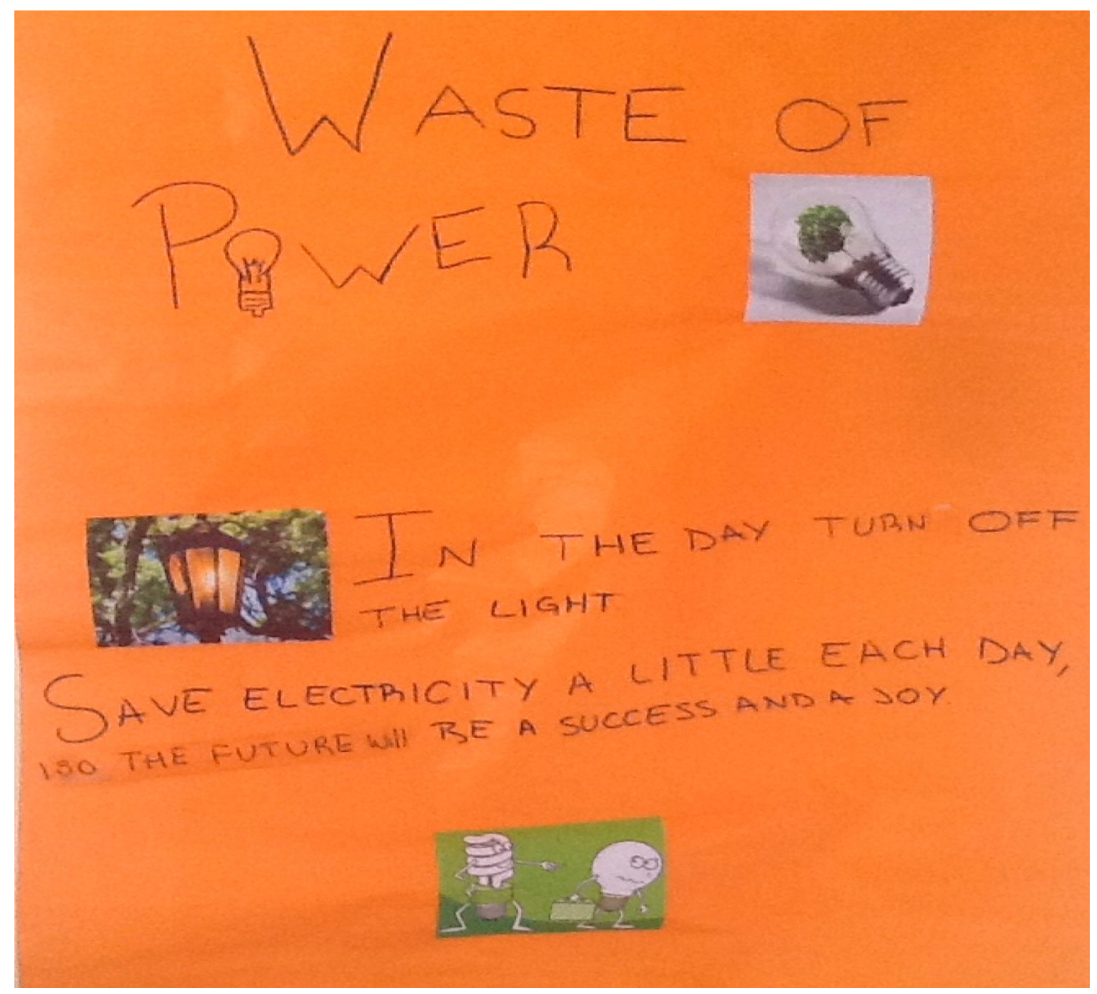

Figure 9. Awareness-raising poster about the environment designed by a group of Argentinian children in their own free time.

them. The use of imperative forms is an example of such direct address ('turn off the light', 'save electricity'). There is here a sense of responsibility to protect the environment for others in the future ('the future will be a success and a joy'), a commitment to take concrete actions ('turn off the light', 'save electricity') to save power and make the world a greener place to live, not only for themselves but for everyone. The future in general 'will be a success', not only their own future. There is a genuine commitment in this green message to make a contribution for others, a sense of social responsibility to encourage others to take care of the environment as well, and a positive spirit in the idea that small actions count ('a little each day'). In this sense, this poster is an example of critical cultural awareness (savoir s'engager) (Byram 1997) in the primary classroom which illustrates the discourses of education on hope (Andrews 2010) and which encourages learners to take action to contribute to improving life in this world for everyone (e.g. within Education for Sustainable Development; see Franck and Osbeck 2016).

\section{Significance of the project and this research}

This project is an empirical investigation of intercultural citizenship in the primary EFL classroom and fills a gap that exists in this field. The Argentinian and Danish children engaged critically with a topic of significance to them and did so as an, albeit temporary, transnational community taking action in their world, thus gaining experience of a new identification beyond their national identity, although not replacing it. They explored the topic of the environment with a comparative perspective by interacting with others online using three languages. As an outcome of their cooperation, they planned and implemented some civic and social actions in their communities, actions intended to protect the environment. In this sense, this project can be seen as an example of ethical critical literacy within Education for Sustainable Development in Franck and Osbeck's (2016) terms as it helped children 'catch sight of visions of a sustainable world', take action accordingly, and in this way 'practice, 
protect and promote' everyone's right to a greener world (Dunhill 2016). This occurred as the children engaged in social and civic actions outside the classroom and this is an important first step toward 'outdoor learning' (O'Brien 2009; Waite 2011) in countries like Argentina where this is totally uncommon. Here the children explored their neighbourhoods in search of green crimes accompanied by parents and siblings, and one group created an awareness-raising video in a local square, also accompanied by some parents.

The starting point is that language teaching has instrumental purposes but also educational purposes, amongst which are the development of the self and of societies. Byram (2008) recognises the potential role of foreign language education in citizenship, political and moral education through the development of critical cultural awareness (Guilherme 2002; Houghton et al. 2013). This is especially important in the field of English language education considering the status of English as a global language and associated problems connected, for example, to linguistic imperialism (Phillipson 1992), ideology (Holliday 2011) and native-speakerism (Holliday 2005; Houghton and Rivers 2013). The significance of this study outside Argentina and Denmark (the countries involved) lies precisely in this educational dimension of ELT.

Citizenship education and interculturally oriented language education, what is called here 'intercultural citizenship', both aim at developing learners' competences in analysis, cooperation and knowledge about societies and the socio-cultural environment through critical literacy. The basis for the development of intercultural citizenship skills and competences is the critical literacy experience that the project fostered through the engagement in multiple and varied literacy practices in the foreign language (English) as well as the native languages (Spanish, Danish). The civic actions in the community that the Argentinian children carried out (e.g. Figures 7 and 8) are evidence of the highest level of criticality described by Barnett (1997), called 'transformatory critique in action'. This 'criticality in action' occurred in the EFL primary classroom in this Argentinian setting.

\section{Final remarks}

Some observations are important. First, this project was initially planned by the researchers in both countries and the implementation stage was undertaken with the cooperation of the teachers involved. However, similar projects can be designed by teachers on their own and become a form of action-research or pedagogic innovation. Figure 10 includes reflection questions that teachers can use to clarify their thoughts on intercultural citizenship as well as easy steps to incorporate intercultural citizenship in their classrooms for the first time.

Second, the planning and piloting took a long time (over a year) and this needs to be acknowledged, but the reason is that the project aimed to test the theory of intercultural citizenship in practice for the first time (as well as the other projects reported in Byram et al. 2016), in this case in a primary school setting. However, the description in this article of the essential elements of an intercultural citizenship project in the foreign language classroom will facilitate implementation by others in different contexts.

Third, it was relatively easy for us to find an international group to work with because both researchers were members of a professional network called Cultnet and were in touch. Teachers can find partners at the platform for teacher collaboration of the European Union (http://unicollaboration.eu/), Connecting Classrooms British Council (https://schoolsonline.britishcouncil.org/ about-schools-online/about-programmes/connecting-classrooms), teacher forums and listservs, etc.

Finally, the project itself was time-consuming and required the researchers' commitment and dedication as well as the teachers'. Just to give an example, because of the time difference between Argentina and Denmark, in order to arrange the Skype conversation it was necessary to move the English lesson in Argentina from its original slot to the early morning while the Danish children had to stay after school time. In this sense, the cooperation of the teachers and researchers, the children and their parents and the school authorities was essential. 


\begin{abstract}
In language education, intercultural citizenship combines language teaching from an intercultural perspective with citizenship education. Educators have the moral and ethical responsibility to adopt a citizenship and human rights perspective in the language classroom. The following are some
\end{abstract} reflection questions to trigger your thoughts:

a) What role do you see for yourself as an(a) (foreign language) educator?

b) Why should a citizenship and human rights framework be part of (language) education?

c) Have you ever conscientiously included a citizenship and human rights focus in your (foreign language) lessons? How? Please describe the experience.

d) If you haven't, how could you do so?

e) What might intercultural citizenship in the (foreign language) classroom involve in practical terms?

If you now wish to take action, here are some easy steps:

1) Choose a theme of social import that highlights the universal principles of democratic citizenship and human rights education (e.g. the environment, ecology, languages, peace and conflict, war, diversity, linguistic and other rights, etc.). You can invite children to choose the theme collaboratively.

2) Find a partner. This can be another classroom in your same school, in a different school in your city or a different city, or in another country. Seek permissions from both schools, all teachers involved, and parents.

3) Work together with your partner teacher to plan and implement an intercultural citizenship project around the selected theme with four stages: introductory, research, dialogue and citizenship. Collect project products (e.g. posters, recorded Skype conversations, etc.) for analysis and evaluation of the project.

4) Make sure that more than one language is used in the project and that children take action in the local and/or global communities.

Figure 10. Reflection questions for teachers.

\title{
Conclusion
}

This article describes a telecollaboration experience in the primary EFL classroom between Argentina and Denmark carried out in 2013/2014. The project combines ELT with citizenship education and is based on the idea that foreign language teaching has both instrumental (language-oriented) purposes and citizenship (educational) purposes. It is designed as a case study with a comparative perspective involving three languages (English, Spanish and Danish) and a collaborative task-based orientation that encouraged the children in both countries to address a topic of common interest such as the environment with a genuine purpose, namely to raise awareness of the importance of taking care of the environment globally. Conversational and documentary data were analysed qualitatively and findings indicate that the children developed a sense of bonding amongst themselves, called transnational identification; they developed intercultural citizenship skills such as consciousness-raising, comparative interpretation and critical thinking; and finally they developed critical cultural awareness by designing civic actions in their communities, beyond the classroom and the school. 


\section{Acknowledgements}

I wish to thank Michael Byram for the opportunity to join his network of intercultural citizenship projects in 2012. I am also grateful to Petra Daryai-Hansen, the researcher in Denmark, and to María Emilia Arcuri, Agustiza Zoroza and Kira Schifler, the classroom teachers in both countries. María Emilia Arcuri in particular participated enthusiastically in the design of the classroom materials for the pilot study. A final word of appreciation goes to both schools and the children involved for supporting the project at all times.

\section{Disclosure statement}

No potential conflict of interest was reported by the authors.

\section{Funding}

This work was supported by Instituto de Investigaciones en Humanidades y Ciencias Sociales (Universidad Nacional de La Plata and CONICET).

\section{References}

Andrews, P. 2010. "Hope and the Many Discourses of Education." Cambridge Journal of Education 40 (4): $323-326$. Barnett, R. 1997. Higher Education: A Critical Business. London: Open University Press.

Byram, M. 1997. Teaching and Assessing Intercultural Communicative Competence. Clevedon: Multilingual Matters. Byram, M. 2008. From Foreign Language Education to Education for Intercultural Citizenship. Clevedon: Multilingual Matters.

Byram, M. 2009. "Intercultural Competence in Foreign Languages. The Intercultural Speaker and the Pedagogy of Foreign Language Education." In The SAGE Handbook of Intercultural Competence, edited by D. Deardorff, 321-332. California: Sage Publications.

Byram, M. 2014a. "Twenty-Five Years on - from Cultural Studies to Intercultural Citizenship." Language, Culture and Curriculum 27 (3): 209-225.

Byram, M. 2014b. “Competence, Interaction and Action. Developing Intercultural Citizenship Education in the Language Classroom and Beyond." In Intercultural Communication Competence: Conceptualization and Its Development in Cultural Contexts and Interactions, edited by X. Dai, and G. Chen, 190-198. Newcastle/Tyne: Cambridge Scholars Publishing.

Byram, M., M. Barrett, J. Ipgrave, R. Jackson, and M. C. Méndez García. 2009. Autobiography of Intercultural Encounters: Version for Younger Learners. Strasbourg: Council of Europe Publishing.

Byram, M., I. Golubeva, H. Han, and M. Wagner, eds. 2016. From Principles to Practice in Education for Intercultural Citizenship. Bristol: Multilingual Matters.

Cenoz, J. 2015. "Content-Based Instruction and Content and Language Integrated Learning: The Same or Different?" Language, Culture and Curriculum 28 (1): 8-24.

Cohen, L., L. Manion, and K. Morrison. 2011. Research Methods in Education. 7th ed. London: Routledge.

Copland, F., and S. Garton. 2014. "Key Themes and Future Directions in Teaching English to Young Learners: Introduction to the Special Issue." ELT Journal 68 (3): 223-230.

Council of Europe. 2001. Common European Framework of Reference for Languages. Strasbourg: Council of Europe.

Dunhill, A. 2016. "Does Teaching Children about Human Rights, Encourage them to Practice, Protect and Promote the Rights of Others?" Education 3-13, doi:10.1080/03004279.2016.1165717.

Franck, O., and C. Osbeck. 2016. "Challenging the Concept of Ethical Literacy within Education for Sustainable Development (ESD): Storytelling as a Method within Sustainability Didactics." Education 3-13. doi:10.1080/03004279. 2016.1201690.

García, O. 2009. Bilingual Education in the 21st Century: A Global Perspective. West Sussex: Wiley-Blackwell.

Gee, J. P. 2012. Social Linguistics and Literacies: Ideology in Discourses. London: Routledge.

Gomm, R., M. Hammersley, and P. Foster, eds. 2000. Case Study Method. London: Sage.

Guilherme, M. 2002. Critical Citizens for an Intercultural World. Foreign Language Education as Cultural Politics. Clevedon: Multilingual Matters.

Hagood, M., and E. Skinner. 2012. "Appreciating Plurality Through Conversations Among Literacy Stakeholders." Journal of Adolescent \& Adult Literacy, 56: 4-6.

Handsfield, L., T. Dean, and K. Cielocha. 2009. "Becoming Critical Consumers and Producers of Text: Teaching Literacy with Web 1.0 and Web 2.0." The Reading Teacher, 63: 40-50.

Holliday, A. 2005. The Struggle to Teach English as an International Language. Oxford: Oxford University Press.

Holliday, A. 2011. Intercultural Communication and Ideology. London: Sage Publications. 
Houghton, S. A., Y. Furumura, M. Lebedko, and L. Song, eds. 2013. Developing Critical Cultural Awareness: Managing Stereotypes in Intercultural (Language) Education. Newcastle: Cambridge Scholars Publishing.

Houghton, S. A., and D. Rivers, eds. 2013. Native-Speakerism in Japan: Intergroup Dynamics in Foreign Language Education. Bristol: Multilingual Matters.

Kramsch, C. 2011. "The Symbolic Dimensions of the Intercultural." Language Teaching, 44: 354-367.

Maley, A., and R. Bolitho. 2015. "Creativity." ELT Journal 69 (4): 434-436.

Mertens, D. 2015. Research and Evaluation in Education and Psychology: Integrating Diversity with Quantitative, Qualitative and Mixed Methods 4th ed. Los Angeles, CA: Sage.

Ní Chróinín, D., S. Ní Mhurchú, and T. J. Ceallaigh. 2016. “Off-Balance: The Integration of Physical Education Content Learning and Irish Language Learning in English-Medium Primary Schools in Ireland." Education 3-13, doi:10.1080/ 03004279.2016 .1170404$.

O'Brien, L. 2009. "Learning Outdoors: The Forest School Approach." Education 3-13 37 (1): 45-60.

O'Dowd, R. 2015. "The Competences of the Telecollaborative Teacher." The Language Learning Journal 43 (2): $194-207$. Osler, A., and H. Starkey. 2010. Teachers and Human Rights Education. Stoke-on-Trent: Trentham Books.

Phillipson, R. 1992. Linguistic Imperialism. Oxford: Oxford University Press.

Porto, M. 2016. "Ecological and Intercultural Citizenship in the Primary English as a Foreign Language (EFL) Classroom: An Online Project in Argentina." Cambridge Journal of Education 46 (4): 395-415.

Tin, T. B. 2013. "Towards Creativity in ELT: The Need to Say Something New." ELT Journal 67 (4): 385-397.

Waite, S. 2011. "Teaching and Learning Outside the Classroom: Personal Values, Alternative Pedagogies and Standards." Education 3-13 39 (1): 65-82.

Yin, R. K. 2009. Case Study Research. Design and Methods. 4th ed. London: Sage. 